\title{
AÇÃO COLETIVA PASSIVA: A CLASS ACTION BRASILEIRA
}

\section{Luciano Alves Rodrigues dos Santos*}

Sumário: 1 Introdução; 2 A origem da ação coletiva passiva no Direito Comparado: class actions e defendant class actions; 2.1 As ações coletivas passivas no Direito Inglês; 3 A ação coletiva passiva no ordenamento jurídico brasileiro; 3.1 Da admissibilidade; 3.2 A legitimidade para propositura de ação coletiva passiva; 3.3 Ausência de dispositivos normativos específicos; $3.4 \mathrm{O}$ problema da correta ou adequada representação; $3.5 \mathrm{Os}$ efeitos da coisa julgada frente à admissibilidade de ação coletiva passiva; 4 Exemplos de ações coletivas passivas; $5 \mathrm{~A}$ ação coletiva passiva frente aos anteprojetos de Códigos de Processos Coletivos; 6 Considerações finais.

Resumo: O artigo apresenta os traços gerais da ação coletiva passiva no ordenamento jurídico brasileiro, com enfoque inicial no âmbito comparado. Consiste a ação coletiva passiva na possibilidade de certa coletividade ou grupo de pessoas atuarem no polo passivo de demanda envolvendo interesses transindividuais, com devida e adequada representação. Embora inexistam dispositivos legais que a disciplinem no Brasil, a doutrina e parte da jurisprudência vêm admitindo-a, inclusive nos anteprojetos de Códigos de Processos Coletivos, embora os mais recentes se encontrem arquivados. Trata-se de instituto inovador, que depende de uma série de outros requisitos legais, inclusive constitucionais, para que possa galgar admissibilidade.

Palavras-chave: Ação coletiva passiva. Coletividade. Interesses transindividuais.

\footnotetext{
* Mestre em Direito Negocial pela Universidade Estadual de Londrina (ênfase em Direito Processual Civil). Especialista em Ciências Criminais pela Universidade Católica Dom Bosco. Graduado em Direito pela Universidade Paulista. Professor das Faculdades Integradas de Cacoal (UNESC). Revisor de periódicos.
} 


\section{Introdução}

O propósito do presente trabalho é enfocar as ações coletivas passivas no ordenamento jurídico brasileiro. Entretanto, é imprescindível que se faça um apanhado geral de toda a sua genealogia, nos planos comparados norte-americano e inglês, nos quais se funda toda a ideia.

No Brasil, ante toda a ausência normativa, indaga-se acerca de sua admissibilidade, já que muitos fatores diversos - e mesmo contrários — incidem, como a questão da legitimidade, já que é patente que a Lei de Ação Civil Pública apenas definiu o rol ativo, bem como a própria coisa julgada, que vinculará pessoas que nem ao menos participaram do processo, o que acarretaria em grave dano às garantias constitucionais do contraditório e ampla defesa. Incide neste ponto, também, a questão da correta representatividade.

Contudo, não deixam de existir exemplos em todo o ordenamento, bem como propostas de reformas legislativas, como os anteprojetos de Códigos de Processos Coletivos (a maioria já arquivada), que trazem, dentre os seus artigos, a previsão da ação coletiva passiva.

\section{A origem da ação coletiva passiva no Direito Comparado: class actions e defendant class actions}

Antes de se adentrar a qualquer aporte aprofundado sobre o tema em pauta, é preciso demonstrar que toda a base conceitual da ação coletiva passiva tem gênese no Direito Comparado, mais precisamente nas class actions do sistema norte-americano (Common Law).

Segundo Cássio Scarpinella Bueno:

A class action do direito norte-americano pode ser definida como o procedimento em que uma pessoa, considerada individualmente, ou um pequeno grupo de pessoas, enquanto tal, passa a representar um grupo maior ou classe de pessoas, desde que compartilhem, entre si, um interesse comum". ${ }^{1}$

Em resumo, consiste na possibilidade de uma ou mais pessoas atuarem face à defesa de determinado interesse transindividual, em posição de representação (ativa ou mesmo passiva), desde que, por óbvio, os interesses tutelados em juízo sejam comuns.

1 BUENO, Cassio Scarpinella. As class actions norte-americanas e as ações coletivas brasileiras: pontos para uma reflexão conjunta. Revista de Processo, São Paulo, v. 82, 1996, p. 93. 
Contudo, segundo apontam Luiz Fernando Bellinetti e Thiago Caversan Antunes, "naquelas ações em que todos os membros de um determinado grupo estiverem no polo ativo ou passivo da demanda, em litisconsórcio, não se verificará, propriamente, as class actions". ${ }^{2}$

O primeiro marco que se tem das class actions norte-americanas remonta o ano de 1912, com a promulgação da Equity Rule $38,{ }^{3}$ que previu que as partes, fossem no polo passivo ou ativo da demanda, poderiam fazer-se substituir por representante adequado, vinculando totalmente a coletividade. ${ }^{4}$

Outro grande ponto histórico que se tem das referidas class actions remonta o ano de 1938, com previsão da Rule 23, da Federal Rules of Civil Procedure, que consistem no principal conjunto de mecanismos legais para a tutela dos interesses transindividuais da América do Norte.

Segundo a Rule 23 (a), ${ }^{5}$ há como subespécie de class action a defendant class action, que nada mais é do que a ação coletiva passiva que se tem conhecimento no Brasil, como adiante se verá, a qual dispõe que um ou mais membros de uma classe podem ser demandados quando se estiver diante de interesses comuns transindividuais. ${ }^{6}$

Note-se, contudo, que no direito norte-americano as defendant class actions, assim que propostas, vinculam toda a coletividade, já que se possui plena validade a representação assumida em juízo, conquanto condicionada a certos requisitos essenciais, verificados ex officio - e a todo o tempo no processo - pelo juiz.

Nesse ponto, Arruda Alvim esclarece que a representação no sistema americano "é compreensível [...], diante da circunstância de que, previamente,

2 BELLINETTI, Luiz Fernando; ANTUNES, Thiago Caversan. Ação coletiva passiva: novidade ou inconstitucionalidade? In: Encontro Nacional do Conpedi, 19., 2010, Florianópolis. Anais... Florianópolis: Fundação Boiteux, 2010, p. 324.

3 O propósito geral de composição da Equity Rule 38 (Representantes da classe) reporta-se à questão que deve haver "um de interesse comum ou geral para muitas pessoas que constituem uma classe tão numerosa, bem como por se tornar inviável trazê-las todas perante o tribunal". Isso é orientado para os Estados que possuem elementos de um interesse comum ou geral e numerosas pessoas, como previsto na formação da Equity Rule 38. Disponível em: <http://www.law.cornell.edu/rules/ frcp/ACRule23.htm>. Acesso em: 1 set. 2011. Tradução nossa.

4 TARUFFO, Michele. I limitti soggettivi del giudicato e le 'class actions'. Rivista di Diritto Processuale, Padova, v. 1, 1969, p. 619.

5 Rule 23. Class actions. (a) Pré-requisitos. Um ou mais membros de uma classe podem processar ou ser processados como partes representantes em nome de todos os membros, somente se: (1) a classe é tão numerosa que o litisconsórcio de todos os membros é impraticável, (2) Existem questões de direito ou de fato comum para a classe, (3) As alegações ou defesas das partes representativas são típicas das reivindicações ou defesas da classe, e (4) As partes representantes devem agir de forma justa e proteger adequadamente os interesses da classe. Disponível em: <http://www.law. cornell.edu/rules/frcp/rule23.htm\#rule23 > . Acesso em: 1 set. 2011. Tradução nossa.

6 VIOLIN, Jordão. Ação coletiva passiva: fundamentos e perfis. Bahia: JusPodivm, 2008, p. 103. 
aí não se exigem condições especiais para representar a classe".?

Contudo, há alguns requisitos fundamentais a serem observados após a propositura da demanda, conforme a própria Rule 23 (a): o juiz, para proteger os membros ausentes da classe, poderá criar subclasses; instar o demandante à designação de outro membro da classe para colaborar com o representante; substituí-lo; e determinar a notificação dos demais membros, inclusive determinar que o representante permaneça no polo passivo da demanda, se entender que possui capacidade e possibilidade de defender o interesse dos ausentes em disputa. ${ }^{8}$

Além disso, para que se possa representar a classe, de acordo com a mesma regra acima posta, é imprescindível que essa seja muito numerosa e que a reunião de todos os seus membros seja impraticável; que haja questões de direito ou de fato comuns a ela; que os pedidos ou defesas das partes representantes sejam típicos ou comuns; que as partes representantes protejam eficazmente os seus interesses - da classe.

Há, do mesmo modo, grandes controvérsias no próprio direito norteamericano acerca da correta representatividade, principalmente quando se aduz o termo "eficaz", conquanto o juiz detenha papel fundamental para analisar cada caso, podendo ou não conceder o class certification, ${ }^{9}$ que admite o início da class action. ${ }^{10}$

Com o passar dos anos, a regulamentação federal dessa modalidade de class action (defendant class action) foi seguida por grande parte das leis processuais civis dos Estados norte-americanos, que também passaram a prever as defendant class actions em seus estatutos. Assim, o seu procedimento passou a seguir uma relativa uniformidade.

Vale aduzir, outrossim, que a ideia de defendant class action prevista no sistema norte-americano teve como principal fator de ascensão e

ALVIM, A., apud DINAMARCO, Pedro da Silva. Ação civil pública. São Paulo: Saraiva, 2001, p. 158.

8 Disponível em: $<$ http://www.law.cornell.edu/rules/frcp/index.html\#chapter_iv $>$. Acesso em: 1 set. 2011.

9 Ordem de certificação; Aviso aos membros de classe; Juízo; Classes Questões; Subclasses. (1) Ordem de Certificação. (A) Tempo de Emissão. Desde que possível, após uma pessoa processar ou ser processada como representante de classe, o juiz deve determinar, como forma de certificar se a ação trata-se de uma ação coletiva. (B) Definindo a classe; Nomear Conselho de Classe. Uma ordem que certifica uma ação de classe deve definir a classe e as reivindicações de classe, questões ou defesas, e deve nomear o Conselho de Classe sob a Rule 23 (g). (C) Modificação ou alteração da Ordem. Uma ordem que concede ou nega a certificação à classe pode ser alterada ou modificada antes da sentença transitada em julgado. Disponível em: $<$ http://www.law.cornell.edu/rules/frcp/ rule23.htm\#rule23>. Acesso em: 1 set. 2011. Tradução nossa.

${ }^{10}$ DINAMARCO, P. da S., op. cit., p. 149. 
aceitabilidade a denominada consciência de classe, vez que, como não se dispunha de mecanismos processuais brecantes e de maior força, conquanto idôneos, a coletividade de trabalhadores restava desenfreada, cometendo abusos macroscópicos no plano transindividual. Assim, em vez de se usar da força para coibi-la, era mais que necessário que fossem edificados sólidos meios de contenção, até então desconhecidos da ótica comum litigiosa, calcados por um meio de representação, que a vincularia no todo, desde que adequada e eficaz. ${ }^{11}$

Nos Estados Unidos, as class actions, uma vez adequadamente representadas, não provocam dano ao contraditório ou mesmo à ampla defesa, garantias estas previstas no Brasil constitucionalmente, ainda que a sentença se torne imutável à classe, mesmo sem a participação de muitos dos membros interessados.

Este, com certeza, é o ponto de maior cuidado para se admitir tal instituto no ordenamento jurídico brasileiro.

\subsection{As ações coletivas passivas no Direito Inglês}

Embora a ação coletiva passiva tenha galgado maior difusão no direito norte-americano, pelo problema da consciência de classe anteriormente visto, não há como desprezar alguns dos seus traços iniciais no direito inglês, além de não ser possível determinar se a sua incidência inicial se deu realmente no direito americano ou mesmo no direito anglo-saxão.

Segundo aponta Jordão Violin, o primeiro marco de ação coletiva passiva no sistema anglo-saxão remonta o ano de 1199, quando, na Corte Eclesiástica de Canterburry, um dos párocos ajuizou demanda face aos paroquianos de Nuthampstead, de modo que o direito de receber ofertas, bem como a desnecessidade de realização de missas diárias na Paróquia, fossem concedidos. Não se tratava de ação comum, pois, como se pode notar, consistia em uma coletividade, representada passivamente por somente alguns dos aldeões contra o pedido do pároco. ${ }^{12}$

A existência da defendant class action na Inglaterra, na atualidade, é plenamente admissível, embora guarde sutis diferenças frente ao direito norte-americano, dentre elas a desnecessidade de aceite de representação (class certification) no momento inicial de propositura da demanda, quando

11 MAIA, Diogo Campos Medina. A ação coletiva passiva: o retrospecto histórico de uma necessidade presente. In: Ada Pellegrini Grinover et al. (Coord.). Direito Processual Civil e o Anteprojeto do Código Brasileiro de Processos Coletivos, 2007, p. 321-344.

12 VIOLIN, J., op. cit., p. 103. 
em polo ativo, conquanto se deva fazê-lo ao Tribunal logo que recebida. No polo passivo, contudo, deve-se obter desde o início a autorização judicial. ${ }^{13}$

Embora a admissibilidade de ação coletiva passiva se dê de modo brando quando se pensa em Brasil, nota-se sempre patente, inclusive lá fora, a preocupação legal quando se está em meio a uma representatividade em polo passivo da demanda. Isso ocorre para que não se fira direitos da coletividade, que restará vinculada desde logo, após sentença com trânsito em julgado, sem que se fira outras garantias, amplamente embasadas em textos legais positivados, como adiante se verá, ao se tratar do ordenamento pátrio.

\section{A ação coletiva passiva no ordenamento jurídico brasileiro}

Não restam dúvidas de que a origem brasileira da ação coletiva passiva esteja relacionada diretamente com o direito norte-americano e suas class actions e defendant class actions, como subespécies, desprezando-se a dúvida anterior acerca de possuir berço no modelo inglês ou não.

Como autoconceito, de modo amplificado, consiste a ação coletiva passiva no ato de se prever o ajuizamento de uma demanda contra certa coletividade; um agrupamento humano colocado como sujeito passivo de uma relação jurídica, quando diante de conflito que envolva direito transindividual. A ação, nesses casos, é proposta não pela classe, mas contra ela. É como se pudesse ser possível inverter a Ação Civil Pública: em vez de ser proposta pelos legitimados ${ }^{14} \mathrm{em}$ favor de certa coletividade, seria proposta contra esta.

A justificativa maior para a admissibilidade dessa modalidade de demanda vem bem delineada pelas palavras de Fredie Didier Júnior e Hermes Zaneti Júnior: "da mesma forma que a coletividade pode ser titular de direitos (situação jurídica ativa), ela também pode ser titular de um dever ou um estado de sujeição (situações jurídicas passivas)" ${ }^{15}$

Contudo, ainda devem ser investigados alguns pontos acinzentados face à matéria, já que consiste em assunto de extrema cautela e de

${ }^{13}$ DINAMARCO, P. da S., op. cit., p. 158.

${ }^{14}$ Cf. Art. 5. ${ }^{\circ}$ da Lei n. 7.347/85, in verbis. "Têm legitimidade para propor a ação principal e a ação cautelar: I - o Ministério Público; II - a Defensoria Pública; III - a União, os Estados, o Distrito Federal e os Municípios; IV - a autarquia, empresa pública, fundação ou sociedade de economia mista; V - a associação que, concomitantemente: a) esteja constituída há pelo menos 1 (um) ano nos termos da lei civil; b) inclua, entre suas finalidades institucionais, a proteção ao meio ambiente, ao consumidor, à ordem econômica, à livre concorrência ou ao patrimônio artístico, estético, histórico, turístico e paisagístico".

${ }^{15}$ DIDIER JR., Fredie; ZANETI JR., Hermes. Curso de Direito Processual Civil: processo coletivo. 4. ed. Salvador: Juspodivm, 2009, v. 1, p. 400. 
pouca difusão no meio legislativo, abordada principalmente no campo doutrinário; e com poucos — ou raros — traços jurisprudenciais.

\subsection{Da admissibilidade}

Em linhas gerais, Pedro Lenza defende a possibilidade de existir ação coletiva passiva, embora com pouca base conceitual: "pode-se afirmar ser perfeitamente possível a propositura de ação em face da classe, a fim de se realizar todas as situações práticas [...]". ${ }^{16}$

Nas palavras de Fredie Didier Júnior e Hermes Zaneti Júnior, como anteriormente se exibiu: "da mesma forma que a coletividade pode ser titular de direitos (situação jurídica ativa), ela também pode ser titular de um dever ou um estado de sujeição (situações jurídicas passivas)" ${ }^{17}$

$\mathrm{Na}$ verdade, ainda que se perquira por novas formas e novos regramentos face ao processo civil e à tutela de interesses transindividuais, a admissibilidade das ações coletivas passivas ainda é tema pouco difundido pela doutrina clássica, que opta por se manter inerte.

Além disso, sempre se tratou com mais enfoque da legitimação ativa diante das ações coletivas, o que é ponto preocupante, pois cresce a cada dia a vontade legislativa de se poder usar uma ou mais pessoas no polo passivo de certa demanda, mediante representação.

Enquanto não se possui atividade legislativa no sentido de criar mecanismos para a inserção de uma modalidade de defendant class action no direito brasileiro, a doutrina minoritária acaba se mantendo proativa, no sentido de que uma ação coletiva poderia sim ser ajuizada em face de um agrupamento de pessoas quando houver situação patente de direito material que implique um dever ou estado de sujeição a ele.

Chega-se até mesmo a criar mecanismos diversos, como a ação coletiva passiva originária, que se dá no início de um processo coletivo, sem vinculação a feito anterior; e derivada, quando decorrente de um processo ativo. ${ }^{18}$

E nada disso consiste, entretanto, em convergir censuras à entidade estatal pelo despreparo legislativo, pois, como demonstra José Renato Nalini, "se o próprio conceito de Estado, suas formas e regimes, está a exigir reformulação, todos os seus órgãos e entidades integrantes padecem das mesmas enfermidades lógicas". ${ }^{19}$

\footnotetext{
${ }^{16}$ LENZA, Pedro. Teoria Geral da Ação Civil Pública. São Paulo: Revista dos Tribunais, 2003, p. 203.

17 DIDIER JR., Fredie; ZANETI JR., Hermes, op. cit., p. 400.

${ }^{18}$ DIDIER JR., F.; ZANETI JR., H., op. cit., p. 400.

${ }^{19}$ NALINI, José Renato. O juiz e o acesso à justiça. São Paulo: Revista dos Tribunais, 1994, p. 9.
} 
Do mesmo modo, Arnold Wald retrata que inexiste no Direito qualquer previsibilidade, o que torna descomplicado depreender quão instável se perfaz nosso sistema normativo. ${ }^{20}$

Enfim, são poucos estudos acerca da matéria, ainda problemática em sua maioria, o que dá margem a divagações diversas, as quais devem ser analisadas à luz dos itens que serão, a partir de então, analisados, um a um.

\subsection{A legitimidade para propositura de ação coletiva passiva}

Um dos principais problemas acerca da admissibilidade das ações coletivas passivas incide na questão da legitimidade. E fato é que a própria Lei que disciplina a Ação Civil Pública (Lei n. 7.347/85) traz tão somente o rol de legitimados ativos, em seu art. 5. ${ }^{\circ}$, nada constando do rol passivo. Com isso, muitos se colocam a pensar ser possível que determinada coletividade ou grupo de pessoas pudesse atuar no polo passivo de uma demanda transindividual.

A ideia é pouco embasada, pois sequer trata da questão da representação, como ocorre no direito norte-americano, com as defendant class actions. Se a Lei de Ação Civil Pública tampouco determina quem são os legitimados passivos, do mesmo modo nada dispõe sobre a possibilidade de representação desses.

Diferentemente ocorre, por exemplo, com a Lei n. 4.717/65, que regula a ação popular. Nesta, em seu art. $6 .^{\circ}$, há disciplinado um rol de legitimados passivos:

Art. 6. ${ }^{\circ}$ A ação será proposta contra as pessoas públicas ou privadas e as entidades referidas no art. $1 .^{\circ}$, contra as autoridades, funcionários ou administradores que houverem autorizado, aprovado, ratificado ou praticado o ato impugnado, ou que, por omissas, tiverem dado oportunidade à lesão, e contra os beneficiários diretos do mesmo.

O tema é tão pouco pacífico que alguns doutrinadores chegam a admitir patentemente a propositura de demanda passiva contra certa coletividade, com exceção que se coloque neste polo o Ministério Público, que atuará sempre como fiscal da lei. Isso se deve porque o membro do Parquet não dispõe de personalidade jurídica. ${ }^{21}$

${ }^{20}$ WALD, Arnold. A evolução do direito e a arbitragem. In: LEMES, Selma Ferreira; CARMONA, Carlos Alberto; MARTINS, Pedro Batista. Arbitragem: estudos em homenagem ao Prof. Guido Fernandes Silva Soares. São Paulo: Atlas, 2007, p. 454.

${ }^{21}$ MAGGIO, Marcelo Paulo. Condições da Ação: com ênfase à ação civil pública para a tutela dos interesses difusos. Curitiba: Juruá, 2005, p. 174. 
Contudo, não há como se admitir a mantença de determinado instituto apenas porque nada dispôs a legislação competente, sob pena de se deturpar toda a ordem jurídica do Estado, que se pauta, acima de tudo, pela segurança jurídica em suas relações.

\subsection{Ausência de dispositivos normativos específicos}

Assim como se viu quanto à legitimidade, muitos dos argumentos acerca da admissibilidade de ação coletiva passiva no ordenamento jurídico brasileiro residem na ausência de norma específica que disciplina a matéria.

Um dos doutrinadores contrários a esse posicionamento é Pedro da Silva Dinamarco. Para ele, se inexiste lei que autoriza a defesa em polo passivo de demanda coletiva, não há como se cogitar a presença de ação coletiva passiva até o momento. ${ }^{22}$

Do mesmo entendimento comunga Hugo Nigro Mazzilli, pois, ainda que haja lesão a certa coletividade e ainda que sejam admitidas muitas exceções no Direito brasileiro, não há como se imputar um dever, em demanda coletiva, a essa mesma coletividade, pois se estaria diante de total ilegitimidade. Neste sentido, explica, detalhadamente: "No que diz respeito ao polo passivo da relação processual [...] a lei não autoriza, em regra, a substituição processual dos indivíduos transindividualmente considerados". ${ }^{23}$

Aqueles que defendem a impossibilidade de propositura de ação coletiva passiva, em regra, residem no modo de compreensão da palavra defesa, posta no art. 82 do Código de Defesa do Consumidor, que indica apenas o polo ativo das demandas judiciais.

Nesse sentido, José Marcelo Menezes Vigliar declara que:

Aqueles que negam a possibilidade da existência da demanda coletiva ajuizada em face do representante da coletividade se baseiam, de forma geral, nos próprios termos empregados pela legislação vigente $\left[\ldots . .{ }^{24}\right.$

Desse modo, como a própria legislação processual apenas disciplina que a coletividade atue representada no polo ativo de demanda coletiva, não se poderia cogitar a sua mantença em polo passivo, por total ausência normativa, até bem porque não se pode, jamais, presumir a legitimação extraordinária.

${ }^{22}$ Apud DIDIER JR., F.; ZANETI JR., H., op. cit., p. 219.

${ }^{23}$ MAZZILI, Hugo Nigro. A defesa dos interesses difusos em juízo: meio ambiente, consumidor, patrimônio... 20. ed. São Paulo: Saraiva, 2007, p. 343.

${ }^{24}$ VIGLIAR, José Marcelo Menezes. Defendant class action brasileira: limites propostos para o Código de Processos Coletivos. Disponível em: <http://www.marcelovigliar.com.br/artigo. php?pid=44>. Acesso em: 1 set. 2011. 
José Marcelo Menezes Vigliar novamente de manifesta:

\begin{abstract}
Sempre imaginamos a sociedade como credora da tutela jurisdicional coletiva. Sempre concebemos os representantes adequados como aqueles que se dedicam a curar, em juízo, os interesses mais caros e frágeis da sociedade. Certos interesses transindividuais (como é o caso dos difusos), que não pertencem individualmente a ninguém em particular, mas a todos, simultaneamente, correriam o risco de não serem defendidos em juízo não fosse a substituição processual que se viabiliza pelas ações coletivas.
\end{abstract}

Jordão Violin, em explicação aos dizeres do autor, ainda que guarde relevância, aduz: "demandar em face de uma coletividade não significa priorizar o interesse individual sobre o transindividual. Muitas vezes, um interesse coletivo entra em conflito com outro e isso dá origem a uma ação duplamente coletiva". ${ }^{25}$

Do mesmo modo, poder-se-ia dizer que o art. 107 do CDC preveja a sua possibilidade:

As entidades civis de consumidores e as associações de fornecedores ou sindicatos de categoria econômica podem regular, por convenção escrita, relações de consumo que tenham por objeto estabelecer condições relativas ao preço, à qualidade, à quantidade, à garantia e características de produtos e serviços, bem como à reclamação e composição do conflito de consumo.

Para muitos adeptos, o art. 107 constitui-se num dos exemplos de possibilidade de se demandar judicialmente uma classe em face de descumprimento de qualquer das cláusulas do referido contrato, sendo esta representada judicialmente pela associação da qual faz parte.

Do mesmo modo, o art. 83 do CDC assim dispõe: "Para a defesa dos direitos e interesses protegidos por este código são admissíveis todas as espécies de ações capazes de propiciar sua adequada e efetiva tutela".

Neste ponto, pelos próprios dizeres de Cândido Rangel Dinamarco, poder-se-ia reforçar o que acima se deduz, embora com pouca solidez: "o processo precisa ser apto a dar a quem tem um direito". ${ }^{26}$

Diante deste dispositivo, muitos se põem a acreditar ser possível qualquer espécie de demanda para a defesa de interesses transindividuais, inclusive a ação coletiva passiva. ${ }^{27}$

\footnotetext{
${ }^{25}$ VIOLIN, J., op. cit., p. 99.

${ }^{26}$ DINAMARCO, Cândido Rangel. Instituições de direito processual civil. 2. ed. rev. e atual. São Paulo: Malheiros, 2002, p. 365.

${ }^{27}$ Ibid., p.203.
} 
Outro ponto de destaque é posto por Fredie Didier Júnior e Hermes Zaneti Júnior. Em posição favorável à demanda coletiva passiva, apontam que, diante da inexistência de lei e a partir do momento em que não se proíbe o ajuizamento de ação rescisória, cautelar incidental ou mandado de segurança contra ato judicial pelo réu de ação coletiva ativa, poderia se admitir a possibilidade de se responder pela coletividade, em polo passivo. ${ }^{28}$

Os próprios Termos de Ajustamento de Conduta (TACs), segundo aduzidos por Eduardo Damião Gonçalves, criaram vertentes inalcançáveis, o que poderia ocorrer, do mesmo modo, com a ação coletiva passiva se não se buscar impor mecanismos brecantes ou reguladores. ${ }^{29}$

Em conclusão sucinta, Antonio Gidi, que é favorável a uma interpretação legal muito mais flexível, admite a ação coletiva passiva. Para ele, se não há previsão expressa da sua possibilidade, do mesmo modo não se proíbe. ${ }^{30}$

Note-se que inexiste, até o presente momento, um ponto de concordância entre a maioria da doutrina, conquanto não se possa aduzir que, ante a inexistência expressa de determinado dispositivo legal, permitindo ou proibindo certo instituto, dê margem à criação de novos, como é o caso da ação coletiva passiva.

\subsection{O problema da correta ou adequada representação}

A adequada representação dos membros de certa coletividade, se possível fosse a sua demanda em juízo no polo passivo de ação coletiva, é tema que também provoca um senso de inadmissibilidade da ação coletiva passiva.

A preocupação incide, basicamente, nos efeitos da sentença, que a todos vinculará, pela pessoa de um só - o representante - o que daria ensejo à possibilidade de grave prejuízo, sem contar no ferimento às garantias do contraditório e ampla defesa, previstas constitucionalmente. ${ }^{31}$

Diferentemente do Direito Americano, o representante, como anteriormente se observou, possui regras a serem seguidas, impostas pelo próprio juiz da causa. Caso não proceda como determinado, será desde logo substituído. ${ }^{32}$

${ }^{28}$ DIDIER JR., F.; ZANETI JR., H., op. cit., p. 413.

${ }^{29}$ GONÇALVES, Eduardo Damião. In: LEMES, Selma Ferreira; CARMONA, Carlos Alberto; MARTINS, Pedro Batista. Arbitragem: estudos em homenagem ao Prof. Guido Fernandes Silva Soares. 1. ed. São Paulo: Atlas, 2007, p. 150.

${ }^{30}$ GIDI, A. apud VIOLIN, J., op. cit., p. 153.

${ }^{31} \mathrm{Cf}$. art. 5. ${ }^{\circ}, \mathrm{LV}$ da $\mathrm{CF} / 88$ : "aos litigantes, em processo judicial ou administrativo, e aos acusados em geral são assegurados o contraditório e ampla defesa, com os meios e recursos a ela inerentes".

32 VEDOVA, Bianca da Rocha Dalla. Breves Aspectos Acerca da Ação Coletiva Passiva Originária. Disponível em: <www.abdpc.org.br/abdpc/artigos/Bianca\%20Vedova.pdf > Acesso em: 01 set. 2011. 
Do mesmo modo ocorre no Direito Inglês. Na Inglaterra, o juiz é o principal responsável por determinar a mantença do representante no processo, a qualquer tempo.

No Brasil, como a legitimidade é expressa em lei, presume-se devidamente legitimados aqueles pertencentes ao rol específico (art. 5. ${ }^{\circ}$ da Lei de Ação Civil Pública), sem que ocorra a sua verificação no caso concreto.

Desse modo, como não de pode controlar a atividade dos legitimados em ação coletiva no Brasil, do mesmo modo seria perigoso admitir a possibilidade de ação coletiva passiva.

Dentre os argumentos alimentados pela doutrina majoritária acerca do não controle dos legitimados, aduz-se que a coisa julgada nas ações coletivas seria dada apenas para beneficiar os membros do grupo e o fato de o legislador selecionar previamente algumas pessoas se mostra como absoluta presunção. Além disso, o controle judicial seria desnecessário, já que o Ministério Público sempre atua como fiscal da lei. ${ }^{33}$

Este posicionamento, contudo, diverge em alguns pontos, já que há quem defenda o papel de um juiz muito mais ativo, de modo a aferir, no caso concreto, alguns critérios acerca da legitimação daqueles que substituem o agrupamento humano em juízo.

Segundo dispõe Pedro Lenza, quando se está a tratar incisivamente de ações coletivas, ainda que se deva obedecer aos requisitos legais e ao rol de legitimados do art. 5. ${ }^{\circ}$ da Lei de Ação Civil Pública, por exemplo, não é de se assustar que muitos não possuam sequer credibilidade ou conhecimento técnicocientífico para ali estar, o que demonstra que nem sempre a representatividade se mostra adequada ao caso concreto. Dever-se-ia, assim como no modelo americano, haver uma completa varredura pelo próprio juiz da causa. ${ }^{34}$

Como regra, dever-se-ia deixar a cargo da lei disciplinar melhor a matéria, inclusive porque se trata da defesa de direitos transindividuais, o que poderia acarretar dano irrecuperável a toda uma coletividade, ferindo no todo a garantia do devido processo legal estampada em texto constitucional.

Contudo, como sugestão assertiva, interessante seria se, diverso do direito alienígena, a incorreta representação não provocasse uma indevida vinculação da coletividade aos efeitos pétreos da coisa julgada material, podendo-se repropor a ação, individualmente.

Prejudicial seria, contudo, se se admitisse a inserção da coletividade em polo passivo, mediante representação, vinculando-a à decisão, sem qualquer possibilidade de repropositura da demanda, como ocorre no direito americano.

${ }^{33}$ VIOLIN, J., op. cit., p. 65.

${ }^{34}$ LENZA, P., op. cit., p. 194. 
Nesse sentido, conforme dispõem Luiz Fernando Bellinetti e Thiago Caversan Antunes:

É bem verdade que se poderia, eventualmente, arguir que os princípios do contraditório e da ampla defesa, por uma previsão expressa do artigo $5 .^{\circ}, \mathrm{LV}$, seriam destinados, exclusivamente, àqueles que efetivamente figuram como "litigantes" em uma determinada relação jurídica processual, o que não seria bem o caso dos membros de um determinado grupo, categoria ou classe, "substituídos" e "representados" no polo passivo da demanda-mas sim, mais exatamente, de seus "substitutos" e "representantes". 35

Com base no exposto, é lúcido e ao mesmo tempo preocupante perceber que somente estariam abertos ao contraditório os representantes de determinada classe ou grupo.

Por isso, nos projetos de lei futuros, se vier a ser autorizada a ação coletiva passiva, cada vez mais se deve reforçar a ideia de que cabe ao juiz a verificação da correta e adequada representação, constituindo-se em requisito essencial de toda ação coletiva.

\subsection{Os efeitos da coisa julgada frente à admissibilidade de ação coletiva passiva}

Sem dúvidas, o maior problema quanto à admissibilidade de ação coletiva passiva reside nos efeitos da coisa julgada. Desde a edificação do CDC, a coisa julgada sofreu mutações consideráveis, conforme expostas pelos seus arts. 103 e 104:

Art. 103. Nas ações coletivas de que trata este código, a sentença fará coisa julgada: I - erga omnes, exceto se o pedido for julgado improcedente por insuficiência de provas, hipótese em que qualquer legitimado poderá intentar outra ação, com idêntico fundamento valendo-se de nova prova, na hipótese do inciso I do parágrafo único do art. 81;

II - ultra partes, mas limitadamente ao grupo, categoria ou classe, salvo improcedência por insuficiência de provas, nos termos do inciso anterior, quando se tratar da hipótese prevista no inciso II do parágrafo único do art. 81; III - erga omnes, apenas no caso de procedência do pedido, para beneficiar todas as vítimas e seus sucessores, na hipótese do inciso III do parágrafo único do art. 81 .

$\S 1 .^{\circ}$ Os efeitos da coisa julgada previstos nos incisos I e II não prejudicarão interesses e direitos individuais dos integrantes da coletividade, do grupo, categoria ou classe.

${ }^{35}$ BELlinetTI, L. F.; ANTUNES, T. C., op. cit., p. 328. 
$\S 2 .^{\circ}$ Na hipótese prevista no inciso III, em caso de improcedência do pedido, os interessados que não tiverem intervindo no processo como litisconsortes poderão propor ação de indenização a título individual.

$\S 3 .^{\circ}$ Os efeitos da coisa julgada de que cuida o art. 16, combinado com o art. 13 da Lei n ${ }^{\circ} 7.347$, de 24 de julho de 1985, não prejudicarão as ações de indenização por danos pessoalmente sofridos, propostas individualmente ou na forma prevista neste código, mas, se procedente o pedido, beneficiarão as vítimas e seus sucessores, que poderão proceder à liquidação e à execução, nos termos dos arts. 96 a 99.

$\S 4 .^{\circ}$ Aplica-se o disposto no parágrafo anterior à sentença penal condenatória. Art. 104. As ações coletivas, previstas nos incisos I e II e do parágrafo único do art. 81, não induzem litispendência para as ações individuais, mas os efeitos da coisa julgada erga omnes ou ultra partes a que aludem os incisos II e III do artigo anterior não beneficiarão os autores das ações individuais, se não for requerida sua suspensão no prazo de trinta dias, a contar da ciência nos autos do ajuizamento da ação coletiva.

Em resumo, assim se tem como regra: a) nas ações face a interesses difusos, a coisa julgada produzida será erga omnes, tendo-se como exceção a improcedência do pedido por falta de provas, hipótese em que se poderá ajuizar outra demanda coletiva com idêntico teor, bastando nova prova; b) no caso de ações face a interesses coletivos stricto sensu, a coisa julgada será ultra partes, limitada ao grupo, salvo, do mesmo modo, se o pedido for julgado improcedente por insuficiência de provas; c) quanto aos interesses individuais homogêneos, a sentença fará coisa julgada erga omnes, de modo a beneficiar todas as vítimas e seus sucessores; e o julgamento de improcedência do pedido não prejudicará interesses individuais, admitindo-se ações também individuais.

Mantém-se, assim, além da garantia de coisa julgada, o contraditório àqueles que não participaram diretamente do processo.

Questiona-se, contudo, como ficaria tal regra em face de uma ação coletiva passiva, já que se tem sempre uma representação da coletividade? Estaria o art. 103 do CDC apto a adequar-se a ela?

Nesse sentido, é importante o que trata Pedro da Silva Dinamarco, pois a coisa julgada não poderá jamais prejudicar a classe representada. Seria violar o contraditório e todas as demais garantias fundadas no devido processo legal. ${ }^{36}$

Nos Estados Unidos, diverso do Brasil, não se impõe qualquer vedação, sendo que a coisa julgada exara os seus efeitos a todos, independentemente de qualquer outro fato. Porém, lá, diverso daqui, se trata corretamente da adequada representatividade.

${ }^{36}$ DINAMARCO, P. da S., op. cit., p. 271. 
Nesse sentido, aduz Hugo Nigro Mazzilli:

\begin{abstract}
Ainda, poderíamos lembrar que o sistema processual vigente já admite, ocasionalmente, que se forme título executivo erga omnes contra a coletividade, abstratamente considerada, como na própria ação civil pública ou na ação popular julgada improcedente por qualquer motivo que não a mera falta de provas, bem como na ação de usucapião de bens imóveis, ou na ação de anulação de titulo ao portador, julgadas procedentes, nas quais o Ministério Público é citado ou comparece como parte; em outros exemplos, prevê-se a citação de pessoas incertas ou desconhecidas. Também há a possibilidade de serem citados por edital centenas ou até milhares de beneficiários de atos impugnados em ações civis públicas. Mas a rigor, em todas essas hipóteses, não teríamos propriamente, réus incertos no polo passivo. ${ }^{37}$
\end{abstract}

Aponta-se, com isso, que, mesmo se se admitisse a ação coletiva passiva, não se poderia, sob o regime atual brasileiro, impedir que outros membros da coletividade, ainda que representados, interpusessem ações individuais para a tutela dos seus interesses, pois sequer participaram efetivamente do contraditório.

\title{
4 Exemplos de ações coletivas passivas
}

Ainda que incidam discussões sobre a admissibilidade ou não da ação coletiva passiva no direito brasileiro, algumas causas têm levado a crer na sua existência, ainda que de modo indireto e não facultada em lei.

Segundo Jordão Violin, tem-se um exemplo de ação proposta pelo Ministério Público, em maio de 1998, contra um grupo de comerciantes do Estado do Ceará, na comarca de Baturité, em razão da utilização indevida das calçadas para a exposição de seus produtos. Após a instrução do feito, os mesmos foram condenados a retirarem os seus pertences. E note-se, segundo expõe o autor, que apenas alguns dos comerciantes representaram o grupo no polo passivo. ${ }^{38}$

O mesmo autor traz outro exemplo: uma ação civil pública proposta em face de um sindicato de combustíveis, em 2004, na cidade de Curitiba/ PR, pelo Ministério Público. Note-se que o sindicato possui representação. Se não a tivesse, não teria efeito algum tal demanda, pela até então inadmissibilidade da ação coletiva passiva. ${ }^{39}$

\footnotetext{
37 MAZZILI, H. N., op. cit., p. 343.

38 VIOLIN, J., op. cit., p. 94.

39 Ibid.
} 
Vários são os exemplos, mas não se pode chegar a concluir que se trata realmente de ação coletiva passiva, mas, talvez, de ações plúrimas.

Porém, interessante jurisprudência põe em dúvida todo o comento:

Processo: AD 100070019698 ES 100070019698

Relator(a): SAMUEL MEIRA BRASIL JUNIOR

Julgamento: 12/06/2008

Órgão Julgador: TRIBUNAL PLENO

Publicação: 14/07/2008

Ementa:

AÇÃO COLETIVA PASSIVA (DEFENDANT CLASS ACTION). ILEGITIMIDADE PASSIVA. AUSÊNCIA DE INTERESSE DE AGIR. PRECATÓRIO DA TRIMESTRALIDADE (LEI N. 3.935/87). INCONSTITUCIONALIDADE. PRECEDENTES VINCULANTES DO SUPREMO TRIBUNAL FEDERAL. RELATIVIZAÇÃO DA COISA JULGADA. PROCEDÊNCIA. 1. A classe tem legitimidade para figurar no polo passivo de demanda coletiva, desde que observado o requisito da representatividade adequada, mesmo que não exista previsão normativa explícita. $\mathrm{O}$ ativismo judicial permite seja a admissibilidade inferida das garantias constitucionais do acesso à justiça, da vedação do non liquet, do due process of law e outras, pois não se deve excluir a priori, de lege lata, a via do acesso à justiça contra a classe, porquanto a defining function do juiz, própria das ações coletivas (ativas ou passivas), autoriza a solução judicial de situações justapostas às previstas em lei.

2. A procedência da demanda coletiva passiva (defendant class action) afeta a esfera individual dos associados independentemente do exercício pessoal do contraditório. Com maior razão se participam, em polos invertidos, exatamente aqueles que figuraram na demanda geradora do ato objurgado.

3. A inexigibilidade da obrigação, por ineficácia do título judicial (sentença ou acórdão) fundado em lei ou ato normativo declarado inconstitucional pelo Supremo Tribunal Federal ou em aplicação ou interpretação tidas por incompatíveis com a Constituição da República, pode ser reconhecida quando a declaração ocorreu [...] em controle concentrado ou difuso (independentemente de resolução do Senado) (REsp 803099/SP, Relator Ministro TEORI ZAVASCKI, DJ 6.3.2006, p. 253).

4. A irrecorribilidade de uma sentença não apaga a inconstitucionalidade daqueles resultados substanciais política e socialmente ilegítimos, que a Constituição repudia. Daí a propriedade e a legitimidade sistemática da locução, aparentemente paradoxal, coisa julgada inconstitucional. ${ }^{40}$

Chega-se até mesmo a afirmar ativismo judicial, conquanto prática perigosa e atacada pela maioria da doutrina clássica.

Exemplos irão cada vez mais emergir, sendo somente a lei capaz de frear ou acondicionar melhor o instituto, em moldes adaptados à própria Constituição e às garantias que traz.

${ }^{40}$ Disponível em: $<$ http://www.jusbrasil.com.br/jurisprudencia/8309056/acao-declaratoria-incidentalad-100070019698-es-100070019698-tjes>. Acesso em: 1 set. 2011. 


\section{A ação coletiva passiva frente aos anteprojetos de Códigos de Processos Coletivos}

Vários são os anteprojetos de Códigos de Processos Coletivos, embora se deva destacar somente alguns deles, precipuamente no que tange à previsão da ação coletiva passiva.

$\mathrm{O}$ anteprojeto de Antonio Gidi, em seu art. 28, disciplina como deve ser a ação coletiva passiva:

Artigo 28. Ações coletivas passivas:

28. A ação coletiva poderá ser proposta contra os membros de um grupo de pessoas, representados por associação que os congregue.

28.1 A associação representará o grupo como um todo e os membros do grupo. O membro do grupo será vinculado pela sentença coletiva independentemente do resultado da demanda, ainda que não seja membro da associação que o representou em juízo.

28.2 Se não houver associação que congregue os membros do grupo-réu, a ação coletiva passiva poderá ser proposta contra um ou alguns de seus membros, que funcionarão como representantes do grupo.

28.3 Os membros do grupo poderão criar uma associação com a finalidade específica de representá-los em juízo na ação coletiva passiva.

28.4 Os membros do grupo poderão intervir no processo coletivo passivo.

$28.5 \mathrm{O}$ representante terá o direito de ser ressarcido pelos membros do grupo das despesas efetuadas com o processo coletivo, na proporção do interesse de cada membro. ${ }^{41}$

Note-se que, de maior importância, há vinculação das demais pessoas à sentença, independentemente do resultado da demanda (28.1). Contudo, disciplina também a representação adequada, como segue:

3.1 Na análise da adequação da representação, o juiz analisará em relação ao representante e ao advogado, entre outros fatores:

3.1.1 a competência, honestidade, capacidade, prestígio e experiência;

3.1.2 o histórico na proteção judicial e extrajudicial dos interesses do grupo; 3.1.3 a conduta e participação no processo coletivo e em outros processos anteriores;

3.1.4 a capacidade financeira para prosseguir na ação coletiva;

3.1 .5 o tempo de instituição e o grau de representatividade perante o grupo. ${ }^{42}$

${ }^{41}$ Código de Processo Civil Coletivo de Antonio Gidi. Disponível em: <http://bdjur.stj.gov.br/xmlui/ bitstream/handle/2011/18848/C\%C3\%B3digo_de_Processo_Civil_Coletivo.pdf?sequence=1>. Acesso em: 1 set. 2011.

${ }^{42}$ Código de Processo Civil Coletivo de Antonio Gidi, op. cit., loc cit. 


\section{O projeto da UERJ/UNESA reproduz as mesmas disposições, em seu}

art. 42, conquanto com inovações acerca da coisa julgada passiva:

Art. 42 Ação contra o grupo, categoria ou classe. Qualquer espécie de ação pode ser proposta contra uma coletividade organizada ou que tenha representante adequado [...] e desde que o bem jurídico a ser tutelado seja transindividual e se revista de interesse social.

Art. 43 Coisa julgada passiva. A coisa julgada atuará erga omnes, vinculando os membros do grupo, categoria ou classe.

Art. 44 Aplicação complementar à ação coletiva passiva. Aplica-se complementarmente à ação coletiva passiva o disposto neste Código quanto à ação coletiva ativa, no que não for incompatível. ${ }^{43}$

Note-se que há, como fator-problema para o caso, a coisa julgada erga omnes, vinculante a todos os membros, mesmo não participantes do contraditório.

Do mesmo modo, o Código Modelo de Processos Coletivos do Instituto Ibero-Americano de Direito Processual traz igual regra em seu art. 35 e seguintes:

Art. 35. Ações contra o grupo, categoria ou classe. Qualquer espécie de ação pode ser proposta contra uma coletividade organizada ou que tenha representante adequado, nos termos do parágrafo $2^{\circ}$ do artigo $2^{\circ}$ deste código, e desde que o bem jurídico a ser tutelado seja transindividual (artigo $1^{\circ}$ ) e se revista de interesse social.

Art. 36. Coisa julgada passiva: interesses ou direitos difusos. Quando se tratar de interesses ou direitos difusos, a coisa julgada atuará erga omnes, vinculando os membros do grupo, categoria ou classe.

Art. 37. Coisa julgada passiva: interesses ou direitos individuais homogêneos - Quando se tratar de interesses ou direitos individuais homogêneos, a coisa julgada atuará erga omnes no plano coletivo, mas a sentença de procedência não vinculará os membros do grupo, categoria ou classe, que poderão mover ações próprias ou defender-se no processo de execução para afastar a eficácia da decisão na sua esfera jurídica individual.

Parágrafo único. Quando a ação coletiva passiva for promovida contra o sindicato, como substituto processual da categoria, a coisa julgada terá eficácia erga omnes, vinculando individualmente todos os membros, mesmo em caso de procedência do pedido.

Art. 38. Aplicação complementar às ações passivas. Aplica-se complementariamente às ações coletivas passivas o disposto neste Código quanto às ações coletivas ativas, no que não for incompatível.

${ }_{43}$ Disponível em: <http://www.direitouerj.org.br/2005/download/outros/cbpc.doc >. Acesso em: 1 set. 2011. 
Em resumo, quanto à adequada representação, todos são unânimes a tal exigência para que se admita a ação coletiva passiva.

Conquanto a maioria - senão todos — dos anteprojetos restou arquivada, não é impossível que novos advenham em solo brasileiro, com inovações no campo transindividual ou com melhores regramentos, inclusive frente à ação coletiva passiva.

O que não se deve, contudo, é usar de mecanismos que deturpem a própria esfera de atuação do Direito, nem mesmo garantias já positivadas constitucionalmente, como o contraditório e a ampla defesa.

\section{Considerações finais}

Como se observou, não é assunto pacífico tratar das ações coletivas passivas, que no sistema norte-americano imperam com clareza e sem maiores dificuldades, visto que lá se possui o controle daquele que representa a classe, em polo passivo, diverso do Brasil, que se feririam princípios constitucionais, como contraditório e ampla defesa.

Vastas são as controvérsias, porém a maioria situa-se em pisos pouco estáveis, ora aduzindo ausência normativa, ora ausência de rol de legitimados, conquanto não se pode somente pautar por esses requisitos para admissibilidade de instituto pouco comentado e, com certeza, até o momento, inseguro.

E a insegurança reside no fato de que se trata de instituto que fabricará coisa julgada a todos de uma classe, independentemente de terem ou não alguns dos seus membros participado da demanda coletiva.

Poder-se-ia, no futuro, por meio de novos anteprojetos de Códigos de Processos Coletivos, inserir a ação coletiva passiva de modo a não impedir que a coisa julgada se faça àqueles ausentes, de modo que possam propor ações individuais, como ocorre face ao art. 103 do CDC, garantindo-se, com isso, a ordem constitucional posta desde 1988, não sendo necessário, ainda que raramente, demandar o Constituinte Originário para que, talvez equivocadamente, altere garantias pétreas.

Enfim, usando dos dizeres de Ilya Prigogine frente ao instável ordenamento jurídico brasileiro, sobretudo quando se remete a tratar da seara transindividual: "creio, pelo contrário, que estamos apenas no começo da aventura $[\ldots] "{ }^{44}$

${ }^{44}$ PRIGOGINE, Ilya. O fim das certezas: tempo, caos e as leis da natureza. Tradução Roberto Leal Ferreira. São Paulo: Unesp, 1996, p. 14. 


\section{Passive class action: the brazilian model}

Abstract: The article presents a general study of the defendant class action in Brazilian law, focussing initially in the international scope. The collective action consists in the possibility of a community or a group of persons act to defend a demand involving transindividual interests with a proper representation. Although there are no legal provisions which govern it in Brazil, part of the doctrine and jurisprudence has admitted it, including the project of some codes of Collective Processes, although most of the recent one are filed. It is an innovative institute, which depends on a number of other legal requirements, including constitutional regulations, so that it can be admitted.

Keywords: Defendant class action. Community. Transindividual interests.

\section{REFERÊNCIAS}

BELLINETTI, Luiz Fernando; ANTUNES, Thiago Caversan. Ação coletiva passiva: novidade ou inconstitucionalidade? In: Encontro Nacional do Conpedi, 19., 2010, Florianópolis. Anais... Florianópolis: Fundação Boiteux, 2010.

BUENO, Cassio Scarpinella. As class actions norte-americanas e as ações coletivas brasileiras: pontos para uma reflexão conjunta. Revista de Processo, São Paulo, v. 82, 1996.

DIDIER JÚNIOR, Fredie; ZANETI JÚNIOR, Hermes. Curso de Direito Processual Civil: processo coletivo. 4. ed. Salvador: JusPodivm, 2009, v. 1.

DINAMARCO, Cândido Rangel. Instituições de direito processual civil. 2. ed. rev. e atual. São Paulo: Malheiros, 2002.

DINAMARCO, Pedro da Silva. Ação civil pública. São Paulo: Saraiva, 2001.

GONÇALVES, Eduardo Damião. In: LEMES, Selma Ferreira; CARMONA, Carlos Alberto; MARTINS, Pedro Batista. Arbitragem: estudos em homenagem ao Prof. Guido Fernandes Silva Soares. São Paulo: Atlas, 2007. 
LENZA, Pedro. Teoria Geral da Ação Civil Pública. São Paulo: Revista dos Tribunais, 2003.

MAGGIO, Marcelo Paulo. Condições da ação: com ênfase à ação civil pública para a tutela dos interesses difusos. Curitiba: Juruá, 2005.

MAIA, Diogo Campos Medina. A ação coletiva passiva: o retrospecto histórico de uma necessidade presente. In: Ada Pellegrini Grinover et al. (Coord.). Direito Processual Civil e o Anteprojeto do Código Brasileiro de Processos Coletivos, 2007.

MAZZILI, Hugo Nigro. A defesa dos interesses difusos em juízo: meio ambiente, consumidor... 20. ed. São Paulo: Saraiva, 2007.

NALINI, José Renato. O juiz e o acesso à justiça. São Paulo: Revista dos Tribunais, 1994.

PRIGOGINE, Ilya. O fim das certezas: tempo, caos e as leis da natureza. Tradução Roberto Leal Ferreira. São Paulo: Unesp, 1996.

TARUFFO, Michele. I limitti soggettivi del giudicato e le 'class actions'. Rivista di Diritto Processuale, Padova, v. 1, 1969.

VEDOVA, Bianca da Rocha Dalla. Breves Aspectos Acerca da Ação Coletiva Passiva Originária. Disponível em: <www.abdpc.org.br/ abdpc/artigos/Bianca\%20Vedova.pdf $>$. Acesso em: 01 set. 2011.

VIGLIAR, José Marcelo Menezes. Defendant class action brasileira: limites propostos para o Código de Processos Coletivos. Disponível em: $<$ http://www.marcelovigliar.com.br/artigo.php?pid=44>. Acesso em: 1 set. 2011.

VIOLIN, Jordão. Ação coletiva passiva: fundamentos e perfis. Bahia: JusPodivm, 2008.

WALD, Arnold. A evolução do direito e a arbitragem. In: LEMES, Selma Ferreira; CARMONA, Carlos Alberto; MARTINS, Pedro Batista. Arbitragem: estudos em homenagem ao Prof. Guido Fernandes Silva Soares. São Paulo: Atlas, 2007.

Recebido: outubro/2013. Aprovado: novembro/2013. 